\title{
Techniques of Neutralization in Narratives of Addicted Gamers: A Social Science Approach on Gaming Disorder
}

\author{
Nadine Jukschat ${ }^{1}$ (D)
}

Received: 4 October 2019/Accepted: 23 April 2021/Published online: 14 June 2021

(C) The Author(s) 2021

\begin{abstract}
Due to a hegemony of psychology, the phenomenon of addicted gaming tends to be conceptualized as a chronic illness. Taking a sociological perspective requires reframing the phenomenon: As deviant behavior, and therefore as a behavior, that goes against behavioral expectations of social groups. Such change of perspective raises new questions and sheds light on aspects of the phenomenon that have been unstudied so far. The article takes one step in this direction and applies the concept of neutralization as a heuristic to study how gamers classified as addicted make sense of their deviant gaming practices. Analyses of biographical-narrative interviews with addicted gamers indicate that they use five neutralization techniques in order to carry out their deviant practices without generally questioning social norms, these are rejection of individual responsibility, trivializing revaluation, positive revaluation, revaluation of deviance as self-determined choice and condemnation of instances of social control.
\end{abstract}

Keywords Neutralization theory · Gaming addiction · Internet gaming disorder - Gaming disorder .

Deviant behavior - Qualitative methods

\section{Introduction}

The phenomenon of addictive gaming has gained great attention in the last decades, mainly within psychological research. The appearance of internet gaming disorder as a

Nadine Jukschat

jukschat@dji.de

1 Deutsches Jugendinstitut e. V. (DJI), Franckeplatz 1, Haus 12/13, 06110 Halle, Germany research diagnosis in the appendix of the Diagnostic and Statistical Manual of Mental Disorders-fifth edition (DSM-V) (American Psychiatric Association, 2013), and the decision to include gaming disorder in the 11th revision of the International Classification of Diseases (ICD-11) (World Health Organization, 2018), mark the most recent peak of this development. The phenomenon tends to be conceptualized as a chronic illness, respectively, as a clinically significant phenomenon and to be discussed mainly within a nomothetic paradigm. The premise of this approach is that gaming can indeed be pathologic, in a way that, affected people experience symptoms of a behavioral addiction, show a clinically relevant psychological strain and continue their behavior despite negative psychosocial consequences (Rehbein et al., 2013).

According to ICD-11 gaming disorder "is characterized by a pattern of persistent or recurrent gaming behavior ('digital gaming' or 'video-gaming'), which may be online (i.e., over the internet) or offline, manifested by:

- impaired control over gaming (e.g., onset, frequency, intensity, duration, termination, context);

- increasing priority given to gaming to the extent that gaming takes precedence over other life interests and daily activities; and

- continuation or escalation of gaming despite the occurrence of negative consequences. The behavior pattern is of sufficient severity to result in significant impairment in personal, family, social, educational, occupational or other important areas of functioning.

The pattern of gaming behavior may be continuous or episodic and recurrent. The gaming behavior and other features are normally evident over a period of at least 12 months in order for a diagnosis to be assigned, although the required duration may be shortened if all diagnostic 
requirements are met and symptoms are severe." (World Health Organization, 2020).

It is with the inclusion of gaming disorder in the ICD-11 that researchers in the field of game studies, sociology and communication studies critically entered the scientific discourse on gaming disorder (Aarseth et al., 2017; van Rooij et al., 2018). Up to that point, researchers from these disciplines mostly left the research field of gaming disorder to the more natural science and biomedicine-focused disciplines, at most treating it as a "myth" (Cover, 2006) and instead focused on analyzing e.g., the immanent behavior patterns and interactions within the gaming and online worlds (Jukschat, 2013).

Within the psychological approach, in turn, the need to do research on the phenomenon and for common diagnostic criteria was not debated. The existence of multiple instruments, though, reflects the divergence of opinions in the field regarding what gaming disorder is and how best to diagnose this condition pet (exemplary for this debate: Griffiths et al., 2016; Kuss et al., 2017; Petry et al., 2014, 2016; Rehbein et al., 2015). Besides these discussions on conceptual and diagnostic issues, the main focus in research on gaming disorder is on epidemiology and comorbid disorders (exemplary: Kuss \& Griffiths, 2012a, 2012b).

The inclusion of gaming disorder in the ICD-11 has led to a lively and controversial debate between researchers from the clinical sciences or public health disciplines as proponents of the established diagnosis and researchers in the field of game studies, sociology, communication studies, etc. as opponents (exemplary: Aarseth et al., 2017; van Rooij et al., 2018). This emerging exchange and debate across the disciplinary boundaries are important and a value in its own right. Yet, the published papers indicate the discussion rather produced hardened fronts than improving mutual understanding.

With this paper we argue for a constructive and mediatory approach, claiming that social sciences should not treat gaming disorder barely as a "myth" (Cover, 2006) or "moral panic" (Aarseth et al., 2017; van Rooij et al., 2018) but use their analytical potential and methods to contribute to a more nuanced and differentiated understanding of the phenomenon (for such a perspective see also: Jukschat, 2013).

The article takes one step in this direction. It builds on previous work of the author (Jukschat, 2013, 2014a, b, 2016, 2017; Bleckmann \& Jukschat, 2015) and demonstrates exemplarily how fruitful an empirical sociological perspective could be.

Taking a sociological perspective both enables and requires reframing of the phenomenon and thereby, widens the horizon. From a sociological perspective gaming disorder is best-and broader-understood as deviant behavior, and therefore as a behavior that goes against norms, rules and behavioral expectations of social groups (Hillmann, 1994). ${ }^{1}$ With this shift of perspective, individual pathologies recede into the background. Instead, aspects of the phenomenon that have been unstudied so far become focused and visible, such as socio-cultural and biographical conditions of gaming patterns labeled as addictive or the way gamers themselves make sense of their gaming behavior. In a previous study based on interviews with gamers that qualify as present or former addicts (Jukschat, 2017; Bleckmann \& Jukschat, 2015), the authors showed that gamers failing to accomplish several distinguishable biographical quests (for recognition, for belonging, and for autonomy) in "real-life" develop gaming practices that match these quests and thus enable them to gain recognition, belonging or autonomy at least "virtually." It becomes obvious that through gaming these gamers try to conform to social expectations regarding success, social integration, and self-determination, and-paradoxically-at the same time exclude themselves because their gaming practices are perceived as deviant and labeled as "addictive" by society. Taking this result seriously raises the question on how these gamers deal with this paradox. One central point in the process of developing and maintaining an "addictive" gaming behavior calls for an explanation: the very moment when gamers engage and commit in games to the point that they neglect other spheres of life such as family, work, other hobbies or even health. This is when their non-adherence to social norms, values, and expectations becomes obvious and is typically problematized and labeled as an "addiction." Given the fact that the world of the gamer is embedded in the larger world of those who conform to general social conventions and that these gamers cannot be viewed as detached from the moral standards in place in a given society raises a question: How do these gamers meet and answer the demands for conformity claimed by internal and external instances of social control?

The aim of this article is to analyze how gamers classified as addicted deal with this paradox situation and make sense of their deviant gaming practices.

During the research process the concept of neutralization (Becker, 1963; Sykes \& Matza, 1957) popular in sociology and criminology but not within addiction studies prooved helpful as a heuristic or 'sensitizing concept' (Blumer, 1954).

\footnotetext{
${ }^{1}$ For internet addiction Dellwing (2013) made a quite similar proposal. Applying Goffman's work on mental illness as a disturbance of the order of "place" he conceptualizes internet addiction as an ascription to those "whose priorities concerning their time management worry, sadden and anger others" Dellwing (2013, p. 104) and thus deviate from social expectations.
} 
Research on various deviant practices has shown that individuals "resort to neutralization techniques to escape from normative obligations and to carry out deviant practices while continuing to adhere to the norms of their cultural reference group" (Odou \& Bonnin, 2014, p. 104). Neutralization techniques can be understood as excuses or justifications for violations of social norms "that are seen as valid by the delinquent but not by the legal system or society at large" (Sykes \& Matza, 1957, p. 666). They enable people to violate the very norms to which they are at least partially committed and thus, are necessary to continuing deviant behavior. Drawing on their analysis of juvenile delinquency Sykes and Matza (1957) outlined five principal neutralization techniques: denial of responsibility, denial of injury, denial of victims, appeal to higher loyalties, and condemnation of condemners.

In this article, we use the neutralization theory approach as a sensitizing concept to study how gamers labeled as addicted make sense of their gaming practices and how they justify their gaming practices against problematizations through instances of social control. Our main guiding research question is in which way do these gamers legitimize their gaming behavior and how do they neutralize their deviance? Besides this, the study asks: Are the reconstructed techniques of neutralization used exclusively, do they vary, complement or even contradict each other? Moreover, how coherent is the neutralization system? In addition, do the neutralization techniques relate to the biographical gaming motives?

By analyzing biographical narrative interviews with male and female present and former ascribed gaming addicts conducted in Germany, the study identifies and systematizes five such techniques of neutralization and discusses how the reconstructed techniques of neutralization relate to one another. Thereby, the study provides insight into the way "addicted" gamers deal with the normative pressures produced by their gaming practices. Reflecting these findings in the light of the biographical gaming patterns reconstructed earlier on the same empirical data (Jukschat, 2017; Bleckmann \& Jukschat, 2015), the study, furthermore, indicates that the neutralization techniques rather relate to societal discourses on gaming than to individual gaming patterns. In doing so, the study not only contributes to a deeper understanding of the phenomenon of addicted gaming and can be understood as a starting point for further research on gaming disorder from a social science perspective.

\section{Methods}

The presented analyses are based on interviews with 11 male and 9 female gamers aged 16-39 years, that qualify as present or former addicts according to a psychological screening instrument ${ }^{2}$ and/or self-analysis. ${ }^{3}$ They vary regarding socio-demographics (from low-level school education to academic qualification), gaming habits (online and offline gaming) and preferred game genre (e.g., MMORPGs, strategy games, casual games). All interviews have been conducted in Germany between 2010 and 2013 within a broader qualitative-reconstructive study on the subject of gaming disorder that also included gamers with unproblematic gaming habits (see also: Jukschat, 2013, 2014a, 2016, 2017; Bleckmann \& Jukschat, 2015).

Data were collected using biographical narrative interviews (Przyborski \& Wohlrab-Sahr, 2014, 79 ff.; Schütze, 1983, 2007), inviting the interviewees to tell the story of their lives, emphasizing a particular interest in the whole person "behind" the gamer and encouraging them to talk about their whole life without explicitly focusing on gaming. According to the methodological approach, interviewees were encouraged to produce an autobiographical narrative that followed their own lines of thought without being disturbed or even interrupted by any interviewer topicalizations. After finishing their autobiographical extempore narration, priority was given to immanent questions. Only for the last part of the interview, open

\footnotetext{
2 The Video Game Dependency Scale CSAS II by Rehbein, Kleimann, and Mößle (2010) was used as screening instrument. This scale is based on the Internet Addiction Scale (ISS-20) by Hahn and Jerusalem (2001), which the authors extended and adapted to the issue of gaming disorder. The CSAS II followed the classification of dependency of ICD-10 and consists of 14 items (4-point scale: 1, incorrect, to 4 , absolutely true). It covers the following dimensions: preoccupation/salience (4 items; e.g.: "During the time that I do not play video games, in my thoughts I am very much occupied with games." or "It happens that I am virtually doing something completely different and then, without thinking, start a video game."), conflict (4 items; e.g.: "I am so frequently and intensively occupied with video games that sometimes I have problems in school/at work." or "People important to me complain that I spend too much time playing."), loss of control ( 2 items; e.g.: "I often spend more time playing video games than I planned."), withdrawal symptoms (2 items; e.g.: "If I cannot play, I am irritable and dissatisfied."), and tolerance ( 2 items; e.g.: "I have a feeling that video games are getting more and more important for me."). The amount of time spent is not important to qualify as dependent according to that scale (see: Rehbein, Kleimann, and Mößle 2009; Rehbein et al. 2010).

${ }^{3}$ From the perspective of sociology of social problems, a clinical diagnosis for including participants into the study is not as relevant as in psychology because gaming disorder is conceptualized as a gaming practice that goes against social norms and behavioral expectations. In that sense psychologists and their diagnoses can be understood as strong external instances of social control, whereas self-analysis is based on internal instances of social control and processes of selflabeling.
} 
questions on gaming biographies and in-game behavior had been prepared which had been used in a flexible handling order. With this research instrument, it was assured that interviewees could narrate in monolog form and develop their subjective relevance systems. In order not to provoke neutralizations through the researcher and therefore to produce them as an artifact of the interview situation it was consciously avoided in the interview to confront the interviewees with their nonconformity through questions that problematize or pathologize the gaming behavior. Only at the end of the interview, the very last question addressed this aspect. To encourage the interviewees to reflect about their own gaming behavior, they were finally asked what comes into their mind when they hear the term "addiction".

The question of how to address interviewees without subjecting them to moral judgments or producing pressure to legitimize their gaming practices also played an important role in the recruiting strategy: To minimize framing on addiction beforehand, the study was advertised with the broad slogan "Gaming in Germany-between leisure-time activity and addiction". Various channels, such as announcements in online and offline media, in Internet forums for different game genres and at important events in the gamer's scene, were used to inform potential participants about the study. Interested gamers were asked to complete an online screening questionnaire, which in addition to questions regarding gaming habits and sociodemographic data included KFN's CSAS-II-scale for gaming addiction. The prospect of receiving an incentive of 25 Euro upon participation in the interview phase was advertised. In this way, a database could be built up which in the end included around 1100 gamers, 368 of them former or present video game addicts. Interviewees were selected from this database on the basis of minimal and maximal contrasts regarding the emerging themes, motives and concepts, their dimensions and variations (Corbin \& Strauss, 1990; Strauss, 1998).

Interviews lasted between $75 \mathrm{~min}$ to three and a half hours. The interviews were conducted at places selected by the interviewees; in most cases, they chose their homes.

All procedures followed were in accordance with the ethical standards of the responsible committee on human experimentation (institutional and national) and with the Helsinki Declaration of 1975, as revised in 2000 (5). Written informed consent was obtained from all participants for being included in the study.

In line with Grounded Theory Methodology (Breuer, 2009; Glaser \& Strauss, 1967; Strauss, 1998), data were collected and analyzed concurrently to develop a comprehensive theory. An iterative process of moving back and forth between empirical data and emerging analysis, which made the analysis successively more theoretical, characterized research. For the analyses, Grounded Theory Methodology was supplemented by the objective hermeneutic approach, particularly its characteristic extensive sequential analysis line by line (Oevermann et al., 1980; Przyborski \& Wohlrab-Sahr, 2014, 246 ff.). The goal of this reconstructive approach was to reconstruct the latent patterns from the material, or, as Jo Reichertz (2004) puts it for objective hermeneutics: "the 'reconstruction of objective meaning structures' of texts: what the text producers thought, wished, hoped, believed in the creation of their text, that is, what subjective intentions they had, was-and is-unimportant for objective hermeneutics" (Reichertz, 2004, p. 290). For the present study this means: what the interviewees themselves say on a manifest level about their gaming practices, is less important than the latent patterns, which they themselves might not be totally aware of. These latent patterns can be reconstructed and allow for generalization, as they are based on a systematic illumination of the research field, following the principle of continuous comparison to identify contrasting and similar patterns (Bryant \& Charmaz, 2011; Przyborski \& Wohlrab-Sahr, 2014).

Within the research process, techniques of neutralizations emerged and proved relevant to explain, how gamers with a gaming behavior that obviously transgresses social norms, values and expectations manage to keep up their gaming behavior. Interestingly those techniques of neutralization emerged not only when asked to reflect on the gaming practices. Interviewees referred to them repeatedly throughout the whole interviews. This fact indicates the relevance of those neutralizing narratives and interpretations for gamers labeled addicted. Once being sensitized to these techniques of neutralization, analyses and further sampling strategies systematically addressed them until saturation was reached and no new patterns or variations could be identified.

\section{Results}

In order to keep up their non-conforming gaming practices without questioning general norms and values fundamentally, the interviewed gamers-first of all on the level of action-resort to strategies to evade confrontation with the instances of social control. This includes, for example, withdrawing from critical social contexts or covering up gaming habits, including, for example, not to talk about gaming in such contexts or to hide gaming behavior by gaming at night. These strategies deal with the deviance rather defensive and aim to bypass instances of social control. Psychologists would classify these strategies as "deception". Once evading confrontation does not work (any more) and the potential for conflict associated with the 
gaming practice becomes visible for the gamers themselves and/or significant others, neutralizations on the level of interpretation become necessary. In this sense, five main neutralization techniques proved relevant in this study.

Two axes proved helpful to systemize the reconstructed techniques of neutralization and to understand their inherent logic: The $x$-axis represents the way in which the techniques of neutralization relate to social norms and the instances of social control that claim conformity. It goes from approval (on the left side) to hollowing out (on the right side). Where approval means that the social norms and the instances of social control are accepted and approved, hollowing out addresses techniques of neutralization that aim to reject the claims for conformity or to evade the instances of social control. The $y$-axis in contrast represents the way in which gamers deal with their deviance. It ranges from defensive, rather passive and almost abashed ways of thematizing personal gaming behavior (at the top) to offensive, in a way self-confident and empowering interpretations, which come along with a considerable element of self-determination (at the bottom) (Fig. 1).

The five reconstructed neutralization techniques could be ideal-typically located within the graph presented. However, this does not mean these techniques are mutually exclusive. Gamers rather use them as an opportunistic repertoire depending on the context, the situation and the social norms, values and expectations they no longer meet. This point will be explored in more detail after presenting the reconstructed techniques of neutralization.

\section{Rejection of Individual Responsibility for Gaming Behavior}

In the first quadrant, we find one pattern of neutralization that is characterized by great approval of the social norms and the instances of social control but very defensive. Gamers using this technique of neutralization often agree on having problems with their gaming habits but reject individual responsibility by argumentation patterns with fatalistic tenor: "I cannot help it". . One variety of doing so is referring to the games' "addictive structures" and "addictive mechanisms" which more or less determine, as is argued, the development and stabilization of an addiction without any chances for individuals to resist or withstand. A somewhat different variety of this neutralization technique is a legitimization with recourse to biologist argumentation patterns, which can be illustrated by a young

\footnotetext{
4 This technique of neutralization demonstrates great similarities with the "Denial of Responsibility" found by Sykes and Matza (1957). Individual responsibility for actions is denied, rather delinquent actions are interpreted as the inevitable consequence of external circumstances such as poverty, broken home or drunkenness.
}

woman's explanation for her problematic gaming practices: From her point of view, her "brain structure" has already been changed in an almost irreversible way through her gaming activities: "And then the brain is only.. focused on that. And /Mhm./ it is not able to do the other things, that you earlier.. were able to do" (Jenny, 22). "The gamer, in that sense, is reduced to a biological organism and is no longer seen as a subject capable of action and able to make decisions. A third way of neutralizing addictive gaming practices within this neutralization pattern is the delegation of responsibility to external living conditions. Jens, 34, for example, represents this pattern. He presents his gaming addiction as a logical and direct consequence of his epilepsy and the subsequent unemployment: "Yes and through the illness, that I simply have, I am simply very limited, right, and I simply play a lot computer". 6 The perceived inevitability of becoming a gaming addict is especially reflected in the accumulation of the word "simply", which emphasizes his feeling of having no other choice.

\section{Trivializing Revaluation of the Gaming Behavior}

The second pattern in this quadrant is less defensive and therefore placed a little bit below the already described one. The subjective interpretations of the gaming practices appear more ambivalent in this case; there is no clear selfdescription as addicted. The general tenor of this legitimization pattern is best described with the statement "it is not that bad in my case". Two variations of the trivializing revaluation of the gaming behavior that can also be combined, can be found throughout the interviews: Interviewees justify their own gaming habits by the fact that other people play even more and are "really" addicted, or they deny negative consequences of their gaming for other spheres in their lives. An example for the trivializing revaluation through comparison with "worse" gamers in combination with the denial of negative effects in the case of oneself is Lukas, who reflects on his gaming as follows: "I find eh.. I am not addicted or so. /Mhm./(1) I know one, he is.. g-at least in my opinion.. I find that he is addicted.

\footnotetext{
5 Transcription: Underlined-emphasis; speaking pause-two dots for short pauses, number of seconds in brackets for long pauses; slashes, e.g., /Mhm./—short statement by the other person. Names and places are anonymized in all case examples presented. The quotes cited have been translated from German to English for the purpose of this publication by the author, following a documentary translation approach (Wettemann (2012)) attempting to keep the specific character of the original text. All analyses and interpretations follow the original (German) version. German original quote: „Und dann ist das Gehirn nur noch da drauf.. fixiert. Und /Hmhm./ es kann gar nicht mehr die anderen Sachen, die du früher.. gekonnt hast".

${ }^{6}$ German original quote: „Ja und durch die Krankheit, die ich halt habe, bin ich halt sehr eingeschränkt ne, und ich spiele halt sehr viel Computer".
} 
Fig. 1 Neutralization of normative pressure in the case of addicted gaming practices

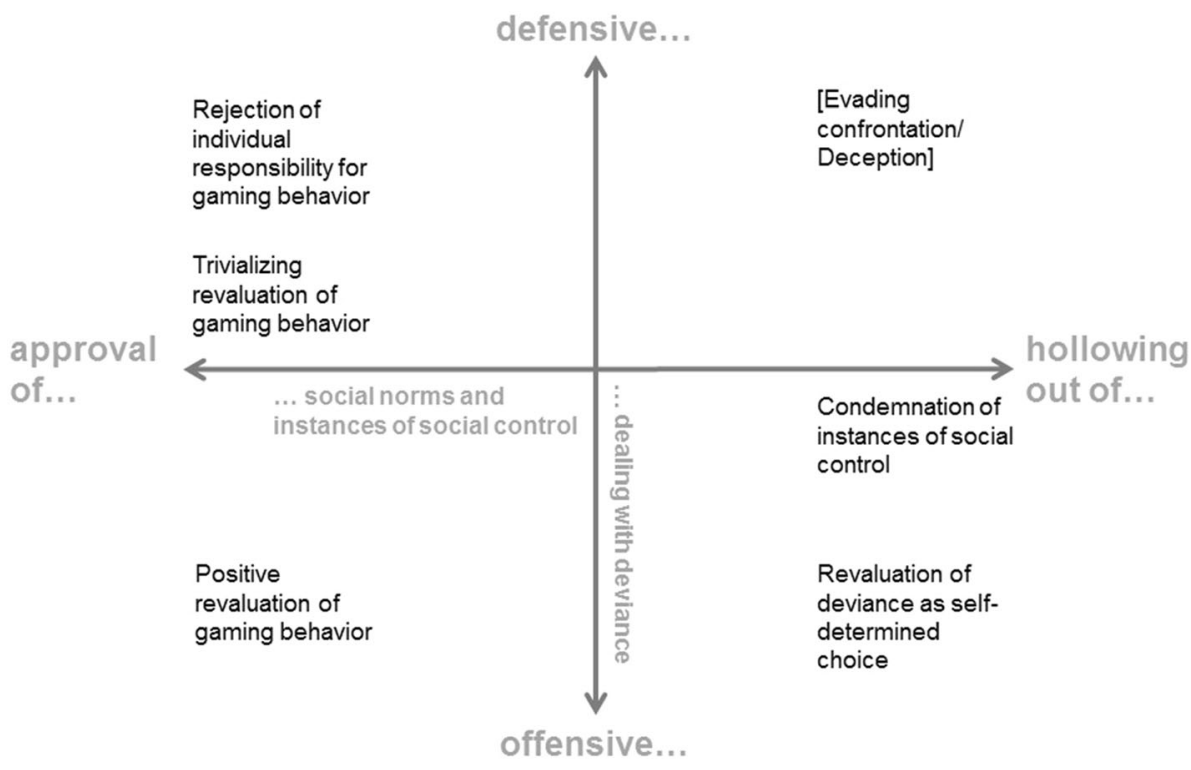

[...] He plays.. even during the week mostly.. ten hours / Mhm./ at night.. yes. If one is with a mobile in Skype / Okay./ one sees he is already online.. /Yes./ still continuously. /Yes./ Yes. (1) He also most-sometimes freaks out. I Okay./(1)" (Lukas, 16). ${ }^{7}$ The claim of not being addicted is presented rather hesitant and ambivalent (with pauses and linguistical relativizations "I find", "or so"), at least not confident. It needs to be secured against self-doubts and towards the interviewer as an instance of social control through the comparison with a boy Lukas knows through gaming. The way Lukas describes this boy's gaming practice makes this visible. Through both, language ("even", "already", "still continuously") and information provided, Lukas construes a big contrast between his own and the other boy's gaming practices. Lukas' presentation especially highlights the extensive amount of time spent for gaming, associated also with a problematized reversal of the night and day rhythm as well as aggressions. Through this dramatizing and pathologization of the gaming habits of the other boy, Lukas diverts attention from his own problems associated with his gaming and at the same time relativizes and trivializes his own gaming practice.

\section{Positive Revaluation of Gaming Behavior}

Still accepting and approving the social norms and instances of social control the third pattern of neutralization

\footnotetext{
7 German original quote: „Ich find äh.. ich bin nicht abhängig oder so. /Mhm/ (1) Ich kenn einen, der ist.. g- soweit meiner Meinung nach.. find ich, dass er abhängig ist. [...] Er spielt.. selbst in der Woche meistens.. zehn Stunden /Mhm./.. nachts.. ja. Wenn man man mit nem Handy in Skype ist /Okay./ sieht man den auch schon online.. /Ja./ immer noch durchgehend. /Ja./ Ja. (1) Der rastet meistmanchmal auch aus.. /Okay./ (1)“
}

revaluates the gaming behavior confidently. Gamers interpret their gaming practices positively as productive activities that do not conflict with certain social expectations and norms and rather, quite in opposite, enable them to achieve certain social objectives. In this sense, certain societal values and norms are emphasized whereas societal expectations that are no longer met remain unexpressed. This technique of neutralization typically comes along with a rhetoric of learning, qualifying and acquisition of competencies through gaming, which is to some extent provided by the gaming industry (exemplaryly: McConigal, 2012). To give only one example, a young woman highly engaged in an online role-playing game set in the Middle Ages, highlights the necessity to read a lot and to inform herself about several matters in order to be able to play her characters authentically: "somehow it also qualifies you [...] one doesn't become stupid in front of it" (Sandra, 25). ${ }^{8}$ Depending on the specific game, gamers emphasize positive effects of their gaming behavior e.g., on language skills, the ability to think strategically or on social skills.

\section{Revaluation of Deviance as Self-determined Choice}

In contrast to the presented techniques of neutralization so far, the revaluation of deviance as self-determined choice offensively rejects certain claims for conformity. Gamers using this fourth technique of neutralization emphasize that they do not want to conform by referring to their individual needs. They do not necessarily reject the norms in general, but rather claim that specific norms and expectations in question do not account for them personally. Jenny, for

\footnotetext{
${ }^{8}$ German original quote: ,irgendwo bildet es auch einen weiter [...] man verdummt nicht davor".
} 
example, who due to her gaming lives more or less socially isolated, refuses claims to participate in social activities by stating: "I have realized also.. (breathes in) that I feel better when I'm alone [...] It's maybe (breathes in deeply) (1) I mean, if you are just rather introverted,.. during puberty you usually probably don't realize it, because you just want to belong (breathes in).. and one doesn't realize, that this actually leaches you out." (Jenny) ${ }^{9}$ In this sequence Jenny interprets her withdrawal from social activities and relations associated with her gaming practice as a result of a maturing and cognitive learning process, which led to the realization that trying to fulfil social expectations in terms of participation in social activities is bad for her wellbeing. She does not refuse general ideas of belonging and sociality but emphasizes that they do not apply for a certain personality type-which is presented as natural and unchangeable. Through this neutralization strategy conflicts in the social sphere can be neutralized. In addition, gamers argue in that sense to level their deviance regarding expectations concerning educational and professional careers, e.g., by devaluating a strong work ethic and labeling it as pathological calling supporters of such an ethic "workaholics".

\section{Condemnation of Instances of Social Control}

The last neutralization technique found in the interviews differs from the revaluation of deviance as self-determined choice in that it does not disqualify certain social norms and expectations but rather the accusers. It shows similarities with the "Condemnation of the Condemners" found by Sykes and Matza (1957). Gamers shift the focus of attention from their own gaming practices to those who disapprove them. Sandra, for example, who skips school regularly due to her gaming and subsequently is faced with criticism from her classmates, denies their right to judge her behavior: "Okay maybe I sk- skip school sometimes but at least I have social competencies". ${ }^{10}$ By discrediting her classmates as socially incompetent, she devalues any form of their criticism from the outset. The effect of this is being reinforced as for Sandra social integrity is of higher value than compliance with formal rules.

\footnotetext{
${ }^{9}$ German original quote: „hab ich halt ooch gemerkt,.. (atmet ein) dass ich mich wohler fühle, wenn ich alleene bin [...] Ist vielleicht (atmet tief ein) (1) ich mein,..., wenn man nun mal eher introvertiert ist,.. in der Pubertät merkt man's meistens wahrscheinlich nicht, weil man halt irgendwo dazugehören will (atmet ein).. und dass man gar nicht merkt, dass einen das eigentlich auslaugt.".

${ }^{10}$ German original quote: „Okay ich sch- schwänze halt vielleicht mal, aber ich hab wenigstens Sozialkompetenz".
}

\section{Flexible Use of Neutralization Strategies}

The five techniques of neutralization found in this study are used extremely flexibly by the interviewees. One and the same gamer can use neutralization techniques located on opposite sides on the axes presented above. Jenny is one good example of this: On the one hand, she agrees being an addict and rejects the responsibility for her gaming practices by referring to her "brain structure" which appears almost irreversibly changed in her presentation. When it comes to her social isolation through gaming, she, on the other hand, revaluates her deviance as a self-determined choice ("I feel better when I'm alone"). Rather than a coherent system of thought, the techniques of neutralization appear as an opportunistic repertoire that gamers refer to depending on the context, the situation and the social norms, values and expectations they no longer meet.

In addition, these neutralization techniques have little to do with the biographical motives that underlie the gaming practices reconstructed earlier in the study (Jukschat, 2017; Bleckmann \& Jukschat, 2015). Gamers do not reflect the latent biographical functions of their gaming and consequently do not refer to them in an attempt to legitimize their gaming practices. Furthermore, these neutralization techniques appear to be more or less detached from actual gaming practices. To neutralize their deviance, gamers take up and integrate semantic units and arguments from public discourses on gaming and gaming addiction, such as those provided by the gaming industry, gaming subculture, or from professional counseling in the context of addiction. Odou and Bonnin (2014) present comparable findings regarding the influences of public discourses on neutralization techniques for neutralization strategies in people involved in illegal downloading. Such discourses seem to open up "an area of tolerance around the norms" (Odou \& Bonnin, 2014, p. 116) that enables deviants to re-label their deviant practices without questioning the existing social order and the dominant norm.

\section{Discussion and Conclusion}

In the first place, gaming is an ordinary legal leisure activity most young people nowadays engage in to some extent (Fritz et al., 2011). Only when gaming reaches an involvement level that leads to conflicts with social norms, values and behavioral expectations, it becomes a social problem, typically labeled gaming addiction. Especially gamers failing to accomplish biographical quests for recognition, belonging or autonomy in "real life" develop such gaming practices attempting to conform to social expectations regarding success, social integration and selfdetermination at least "virtually" (Jukschat, 2017; 
Bleckmann \& Jukschat; 2015). This results in a paradox situation: By attempting to conform to certain social expectations, they exclude themselves because their gaming practices are perceived as deviant. Neutralization techniques serve to cope with this paradox. In order to meet and answer the demands for conformity claimed by internal and external instances of social control and therefore to carry out their gaming practices, "addicted" gamers use five main neutralization techniques: rejection of individual responsibility, trivializing revaluation, positive revaluation, revaluation of deviance as self-determined choice and condemnation of instances of social control. These neutralization techniques have little to do with the biographical motives that underlie the gaming practices nor with actual gaming practices. To neutralize their deviance, gamers take up and integrate semantic units and arguments from public discourses on gaming and gaming addiction, such as those provided by the gaming industry, gaming subculture, or from professional counseling in the context of addiction. This also ties in with the finding that the five techniques of neutralization found in addicted gamers are used extremely flexibly by the interviewees. Rather than a coherent system of thought, they appear as an opportunistic repertoire that gamers refer to depending on the context, the situation and the social norms, values and expectations they no longer meet. This indicates that neutralization takes place on the level of discourse and follows the logic of defense.

Even though neutralization techniques relate to what psychologists capture by the addiction criterion "deception", neutralization goes beyond lying to others or covering up the extent of gaming. Conceptually, techniques of neutralization should rather be understood as part of the narrative process through which "addicted" gamers make meaning out of their lives and gaming practices. Just like understanding the functionality of "addictive" gaming regarding biographical quests interpreting these neutralization techniques as attempts to conform to social expectations might be a considerable complementary starting point for practitioners from psychology and related disciplines working with such gamers.

Regarding future research, further developing the relationships between the techniques of neutralization used and the cultural, medial and societal discourses around gaming in Germany, that have been only briefly sketched in this paper, might be a fruitful path. It might also be promising for further research, to systematically address the neutralization use in contrasting sociocultural milieus and to consider the narratives provided in specific cultural and societal contexts with the help of cross cultural studies. In the context of gaming disorder, for example, comparing the neutralization techniques of German addicted gamers with those of gamers from, for instance, Asian countries, where gaming disorder is a big issue (Yen et al., 2010), might be interesting, especially because popular games are often played throughout the world.

With regard to gaming disorder in general, the study demonstrates how the techniques of neutralization counter normative pressure and contribute to a stabilization of "addicted" gaming practices. It thereby shows-although limited to a small sample and focused on very specific mechanisms in the (social) process of developing and maintaining an addictive gaming behavior-how integrating sociological perspectives into the study of addictive gaming could contribute to a broader understanding of the very complex phenomenon. Such a perspective especially enables shedding light on its social side, the interactional dynamics involved or the mechanisms of stabilizing the self-concept. Aspects which, due to the empirical hegemony of psychological research on gaming disorder, have been mostly unstudied so far but might be quite helpful also for practitioners from psychology and related disciplines working with "addicted" gamers.

Funding Open Access funding enabled and organized by Projekt DEAL.

Open Access This article is licensed under a Creative Commons Attribution 4.0 International License, which permits use, sharing, adaptation, distribution and reproduction in any medium or format, as long as you give appropriate credit to the original author(s) and the source, provide a link to the Creative Commons licence, and indicate if changes were made. The images or other third party material in this article are included in the article's Creative Commons licence, unless indicated otherwise in a credit line to the material. If material is not included in the article's Creative Commons licence and your intended use is not permitted by statutory regulation or exceeds the permitted use, you will need to obtain permission directly from the copyright holder. To view a copy of this licence, visit http://creativecommons.org/licenses/by/4.0/.

\section{References}

Aarseth, E., Bean, A. M., Boonen, H., Carras, M. C., Coulson, M., Das, D., et al. (2017). Scholars' open debate paper on the World Health Organization ICD-11 Gaming Disorder proposal. Journal of Behavioral Addictions, 6(3), 267-270. https://doi.org/10.1556/ 2006.5.2016.088

American Psychiatric Association. (2013). Diagnostic and statistical manual of mental disorders fifth edition DSM-5TM. American Psychiatric Association.

Becker, H. S. (1963). Outsiders. Studies in sociology of deviance. The Free Press.

Bleckmann, P., \& Jukschat, N. (2015). The integrated model of (Dys-) functionality: Reconstructing patterns of gaming as self-medication in biographical interviews with video game addicts. Forum Qualitative Sozialforschung, 16(3), 8.

Blumer, H. (1954). What is wrong with social theory. American Journal of Sociology, 19(1), 3-10. Retrieved from https://brocku. ca/MeadProject/Blumer/Blumer_1954.html 
Breuer, F. (2009). Reflexive grounded theory. Eine Einführung für die Forschungspraxis. VS Verlag für Sozialwissenschaften.

Bryant, A., \& Charmaz, K. (Eds.). (2011). The Sage handbook of grounded theory. Sage.

Corbin, J., \& Strauss, A. (1990). Grounded theory research: Procedures, canons and evaluative criteria. Zeitschrift Für Soziologie, 19(6), 418-427.

Cover, R. (2006). Gaming (ad)diction: Discourse, identity, time and play in the production of the gamer addiction myth. Games Studies. The International Journal of Computer Game Research, 6,1

Dellwing, M. (2013). Addiction diagnoses as involvement controls: The pragmatic value of psychiatric definitions of the situation. RESET-Recherches En Sciences Sociales Sur Internet, 1(2), 103-129

Fritz, J., Lampert, C., Schmidt, J.-H., \& Witting, T. (Eds.). (2011). Kompetenzen und exzessive Nutzung bei Computerspielern: Gefordert, gefördert, gefährdet. Vistas Verlag.

Glaser, B. G., \& Strauss, A. (1967). The discovery grounded theory: Strategies for qualitative research. Aldine.

Griffiths, M. D., van Rooij, A. J., Kardefelt-Winther, D., Starcevic, V., Király, O., \& Pallesen, S. (2016). Working towards an international consensus on criteria for assessing Internet Gaming Disorder: A critical commentary on Petry et al. (2014). Addiction, 111(1), 167-175.

Hahn, A., \& Jerusalem, M. (2001). Internetsucht: Validierung eines Instruments und explorative Hinweise auf personale Bedingungen. In A. Theobald, M. Dreyer, \& T. Starsetzki (Eds.), Handbuch zur Online-Marktforschung. Beiträge aus Wissenschaft und Praxis. (pp. 213-233). Gabler.

Hillmann, K.-H. (1994). Wörterbuch der Soziologie. (4th ed.). Alfred Kröner Verlag.

Jukschat, N. (2013). Extending the study of videogame dependency: Social meaningfulness of "addictive" gaming and self-analyses of dependency. RESET-Recherches En Sciences Sociales Sur Internet, 1(2), 73-102.

Jukschat, N. (2014a). Die (Sehn-)Sucht Nach Verlässlichem Erfolg. Das Verhältnis Von Leistung, Anerkennung und Erfolg im Onlinerollenspiel World of Warcraft. In: D. Hänzi, H. Matthies \& D. Simon (Eds.), Leviathan Sonderband 29. Erfolg Konstellationen und Paradoxien einer gesellschaftlichen Leitorientierung. (pp. 265-279). Nomos.

Jukschat, N. (2014b). Addictive Gaming: Self-analyses of addiction and techniques of neutralizing deviance. In: Presentation at the XVIII ISA World Congress of Sociology, 13th-19th of July. Yokohama: 16.7.2014.

Jukschat, N. (2016). Computerspielabhängigkeit als unwahrscheinliche karriere. Weichenstellungen und Mechanismen im Prozess der Entstehung und Verstetigung. Erste Ergebnisse biografischer Fallanalysen. In: C. Detka (Ed.), Qualitative Gesundheitsforschung. Beispiele Aus Der Forschungspraxis. (pp. 279-298). Verlag Barbara Budrich.

Jukschat, N. (2017). (Sehn-)Sucht Computerspiel: Bedingungen Der Entstehung Und Verstetigung Abhängiger Computerspielpraxis: Ein Rekonstruktiver Ansatz. Beltz Juventa.

Kuss, D. J., \& Griffiths, M. D. (2012a). Internet gaming addiction: A systematic review of empirical research. International Journal of Mental Health and Addiction, 10(2), 278-296. https://doi.org/10.1007/s11469-011-9318-5

Kuss, D. J., \& Griffiths, M. D. (2012b). Online gaming addiction in children and adolescents: A review of empirical research. Journal of Behavioral Addictions, 1(1), 1-20.

Kuss, D. J., Griffiths, M. D., \& Pontes, H. M. (2017). Chaos and confusion in DSM-5 diagnosis of Internet Gaming Disorder: Issues, concerns, and recommendations for clarity in the field.
Journal of Behavioral Addictions, 6(2), 103-109. https://doi.org/10.1556/2006.5.2016.062

McConigal, J. (2012). Besser als die Wirklichkeit!: Warum wir von Computerspielen profitieren und wie sie die Welt verändern. Heyne.

Odou, P., \& Bonnin, G. (2014). Consumers' neutralization strategies to counter normative pressure: The case of illegal downloading. Recherche et Applications en Marketing (English Edition), 29(1), 103-121. https://doi.org/10.1177/2051570714524878

Oevermann, U., Allert, T., \& Konau, E. (1980). Zur Logik der Interpretation von Interviewtexten. Fallanalyse anhand eines Interviews mit einer Fernstudentin. In T. Heinze, H.-W. Klusemann, \& H.-G. Soeffner (Eds.), Interpretationen einer Bildungsgeschichte. Überlegungen zur sozialwissenschaftlichen Hermeneutik (pp. 15-69). päd. extra Buchverlag.

Petry, N. M., Rehbein, F., Gentile, D. A., Lemmens, J. S., Rumpf, H.J., Mößle, T., et al. (2014). An international consensus for assessing internet gaming disorder using the new DSM-5 approach. Addiction, 109(9), 1399-1406. https://doi.org/10. 1111/add.12457

Petry, N. M., Rehbein, F., Gentile, D. A., Lemmens, J. S., Rumpf, H.J., Mößle, T., Bischof, G., Tao, R., Fung, D. S., Borges, G., Auriacombe, M., \& O'Brien, C. P. (2016). Griffiths et al.'s comments on the international consensus statement of internet gaming disorder: Furthering consensus or hindering progress? Addiction, 111(1), 175-178. https://doi.org/10.1111/add.13189

Przyborski, A., \& Wohlrab-Sahr, M. (2014). Qualitative Sozialforschung: Ein Arbeitsbuch (4.th ed.). München: Oldenbourg.

Rehbein, F., Kleimann, M., \& Mößle, T. (2009). Computerspielabhängigkeit im Kindes- und Jugendalter. Empirische Befunde zu Ursachen, Diagnostik und Komorbiditäten unter besonderer Berücksichtigung spielimmanenter Abhängigkeitsmerkmale (No. 108). Hannover.

Rehbein, F., Psych, G., Kleimann, M., Mediasci, G., \& Mößle, T. (2010). Prevalence and risk factors of video game dependency in adolescence: results of a German nationwide survey. Cyberpsychology, Behavior, and Social Networking, 13(3), 269-277.

Rehbein, F., Kliem, S., Baier, D., Mößle, T., \& Petry, N. M. (2015). Prevalence of internet gaming disorder in German adolescents: Diagnostic contribution of the nine DSM- 5 criteria in a statewide representative sample. Addiction, 110(5), 842-851. https://doi.org/10.1002/add.12849

Rehbein, F., Mößle, T., Arnaud, N., \& Rumpf, H. -J. (2013). Computerspiel- und internetsucht. der aktuelle forschungsstand. Der Nervenarzt, 84(5), 569-575.

Reichertz, J. (2004). Objective hermeneutics and hermeneutic sociology of knowledge. In U. Flick, E. V. Kardorff, \& I. Steinke (Eds.), A companion to qualitative research. (pp. 290-295). Sage.

Schütze, F. (1983). Biografieforschung und narratives Interview. Neue Praxis. Zeitschrift Für Sozialarbeit, Sozialpädagogik Und Sozialpolitik, 13(3), 283-293.

Schütze, F. (2007). Biography Analysis on the Empirical Base of Autobiographical Narratives: INVITE-Biographical Counselling in Rehabilitative Vocational Training-Further Education Curriculum. Magdeburg.

Strauss, A. L. (1998). Grundlagen qualitativer Sozialforschung. (2nd ed.). Wilhelm Fink.

Sykes, G. M., \& Matza, D. (1957). Techniques of neutralization: A theory of delinquency. American Sociological Review, 22(6), 664-670. https://doi.org/10.2307/2089195

van Rooij, A. J., Ferguson, C. J., Carras, M. C., Kardefelt-Winther, D., Shi, J., Aarseth, E., et al. (2018). A weak scientific basis for gaming disorder: Let us err on the side of caution. Journal of Behavioral Addictions, 7(1), 1-9. https://doi.org/10.1556/ 2006.7.2018.19 
Wettemann, U. (2012). Übersetzung qualitativer Interviewdaten zwischen Translationswissenschaft und Sozialwissenschaft. In J. Kruse, S. Bethmann, D. Niermann, \& C. Schmieder (Eds.), Qualitative Interviewforschung in und mit fremden Sprachen: Eine Einführung in Theorie und Praxis. (pp. 101-120). Beltz Juventa.

World Health Organization. (2018). Gaming disorder. Retrieved from http://www.who.int/features/qa/gaming-disorder/en/
World Health Organization. (2020). Gaming disorder. Retrieved from https://icd.who.int/browse11/1-m/en\#/ http\%3A\%2F\%2Fid.who.int\%2Ficd\%2Fentity\%2F1448597234

Yen, C. -F., Yen, J. -Y., \& Ko, C. -H. (2010). Internet addiction: Ongoing research in Asia. World Psychiatry, 9(2), 97. https://doi.org/10.1002/j.2051-5545.2010.tb00285.x

Publisher's Note Springer Nature remains neutral with regard to jurisdictional claims in published maps and institutional affiliations. 